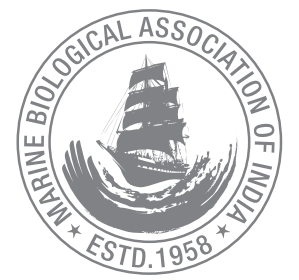

\title{
Can oysters control eutrophication in an integrated fish-oyster aquaculture system?
}

\author{
C. S. Viji”, N.K. Chadha, V. Kripa', D. Prema', Chandra Prakash, Rakesh Sharma, \\ B. Jenni' and K. S. Mohamed ${ }^{1}$ \\ *Central Institute of Fisheries Education, Panch Marg, Off Yari Road, Versova-400 061, Andheri (W), Mumbai. \\ ${ }^{1}$ Central Marine Fisheries Research Institute, P.B. No. 1603, Kochi-18, Kerala, India.
}

*Correspondence e-mail: vijiaquajis@gmail.com

Received: 10 Jul 2014, Accepted: 10 Sep 2014, Published: 15 Nov 2014

Original Article

\begin{abstract}
Eutrophication is a serious problem occurring in ponds or estuaries where fish culture is practised. A possible solution to this problem is to raise oysters in an integrated culture with fish to improve water clarity and to help remove excess nutrients. In order to determine the effects that cultured oysters have on the environment, an experimental study was performed in the Moothakunnam region of the Vembanad lake in the Ernakulam District during February-November, 2012. The study was performed in four cages $(1 \times 1 \times 1 \mathrm{~m})$ referred to as treatments T1, T2, T3 and T4. The four treatments used fish (Etroplus suratensis) and oysters (Crassostrea madrasensis) in the ratio of $1: 0.3,1: 0.5,1: 0.7$ and $1: 0$ respectively. Several parameters were measured and compared between the four treatments, and these included temperature, $\mathrm{pH}$, salinity, dissolved oxygen, biochemical oxygen demand, chemical oxygen demand, total suspended solids, ammonia, nitrite, nitrate and orthophosphate. Results showed that the parameters, DO, BOD, COD, TSS, ammonia and orthophosphate varied with different treatments and months. However, the contents of nitrite and nitrate showed variation only with respect to months. The eutrophication index $(E)$ values calculated for the four treatments were $9.45 \pm$ $4.41,5.25 \pm 3.23,11.32 \pm 6.17$ and $11.52 \pm 5.45$ respectively. The lower $E$ value obtained was for T2 which supports the conclusion that oysters can control eutrophication in an integrated aquaculture system. The optimal co-cultivation proportion of fish to oysters obtained from the present study was 1:0.5.
\end{abstract}

Keywords: Water quality, oysters, integrated culture, nutrients.

\section{Introduction}

According to FAO estimates, aquaculture production has grown dramatically, rising to almost $50 \%$ of world fisheries (Perez, 2012). However, the increasing production through intensified aquaculture systems is affecting the carrying capacity of the environment in which the farming activity takes place, and therefore threatens further development (Casalduero, 2001). Fish farming releases nutrients to the environment causing hypernutrification. Concentrating many animals in a small place creates high oxygen demand and increases the concentration of waste products (Qian et al., 1999), thereby favouring the growth of phytoplankton until the degree of eutrophication situation, thus, challenging the sustainability of aquaculture.

At present, compared to classic monoculture, which involves the inherent risk of being susceptible to environmental problems and to diseases, the concept of integrated aquaculture, which involves organizing a polyculture in a given area is used (Perez, 2012). Applying the principles of integrated aquaculture to existing intensive fish and shellfish farms by 
capturing waste nutrients via lower trophic level organisms, to reduce environmental impacts and yield additional valuable products is gaining interest among farmers. Various studies have suggested the use of invertebrates or demersal fish to assist in the task of sediment remediation.

Integrated aquaculture, recently renamed as integrated multi-trophic aquaculture (IMTA), is a biologically and technically feasible method to reduce the environmental impacts of by-products from fish culture. The main concept of IMTA is to convert the soluble and solid waste products generated by the main culture organism (fish or shrimp) into additional valuable products thereby reducing environmental impacts and increasing the sustainability of the farming operation (Lupatsch, 2012). The concept of developing an "environmentally clean" aquaculture based on an integrated fish - molluscs and macroalgae was first proposed by Gordin et al. (1981). The system was tested in the following years (Gordin, 1982; Gordin et al., 1990; Shpigel et al., 1991). Other authors developed systems integrating fish and macroalgae (McDonald, 1987), fish and shrimp or oyster in land-based facilities (Wang, 1990; Wang et al., 1990; Qian et al., 1999).

Studies have shown that suspension feeding bivalve molluscs can serve as important links between benthic and pelagic processes (benthic pelagic coupling) because they filter large volumes of suspended particles from the water column and eject them as both uningested pseudofeaces and unassimilated feaces which sink to the bottom (Newell, 2004). Bivalve aquaculture differs significantly from the culture of most finfish and crustaceans (Pohle et al., 2001; Crawford et al., 2003) in that cultured bivalves exploit naturally occurring phytoplankton at the base of the estuarine food chain, thus obviating the need for external feed inputs. For this reason, shellfish aquaculture does not result in additional nutrient loading, but rather, a transfer of nutrients from water column particles to benthic sediments in biodeposits, and rapid nutrient cycling when dissolved inorganic nutrients are released into the overlying water, (Dumbauld et al., 2009). The primary purpose of the present study was to evaluate the impacts of farming bivalves along with fish in a cage, on water quality, nutrient concentrations and eutrophication in a tropical estuary.

\section{Study area}

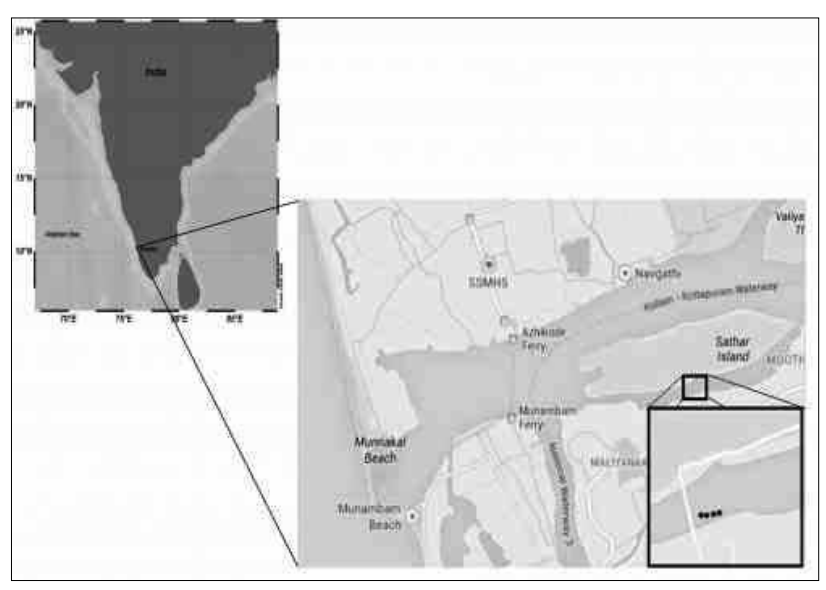

Fig. 1. Map showing the study area. The four points in the inset shows the position of the four treatments.

The study was carried out in Azhikode estuary in Moothakunnam (10011' $\mathrm{N}$ and 76011' E), Ernakulam District, Kerala, India (Fig. 1). The experimental setup consisted of four polyethylene net cages (T1, T2, T3 and T4) which were laid in the direction of the current and the distance between cages was $50 \mathrm{~m}$. Each treatment was made in triplicate. The area of each cage was $1 \mathrm{~m} 2$ and the depth was $1 \mathrm{~m}$. The organisms cultured were the pearl spot, Etroplus suratensis (Bloch) and Indian backwater oyster, Crassostrea madrasensis (Preston). The oyster rens were suspended in the cages. The four cages differed in the stocking

Table 1. Stocking density and ratio of fish to oysters in experimental treatments T1 to T4

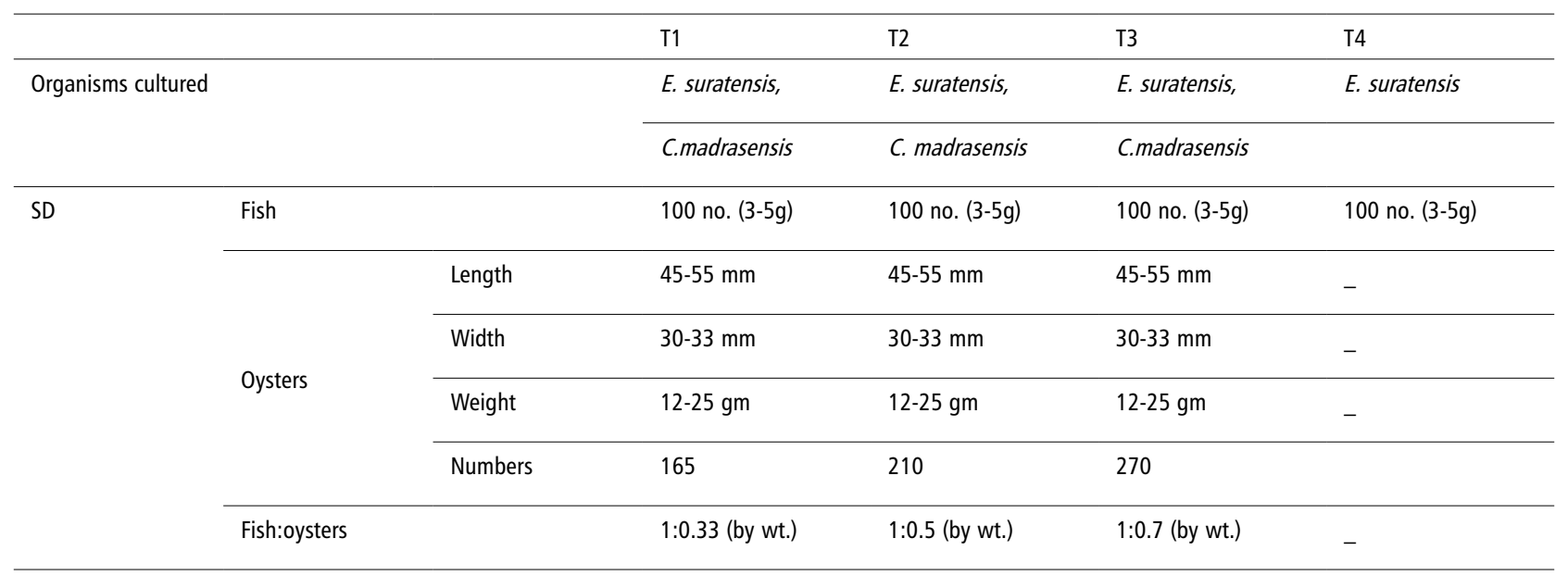

${ }^{*} \mathrm{SD}$ - stocking density ${ }^{*} \mathrm{~T}$ - treatment 
density of the organisms cultured, the details of which are given in Table 1. Fish were fed daily with pelleted feed (protein- $20 \%$, crude fat- $3 \%$, moisture- $10 \%$ ) at the rate of $80-100 \%$ of the body weight initially and $5-8 \%$ during the last phase of culture. The culture period lasted for 270 days.

\section{Field sampling}

Monthly samples were taken from Feb 2012 to Nov 2012. Salinity was measured in practical salinity units (psu) using a hand-held Refractometer (Fischer Scientific, model 304). Temperature was determined using a digital thermometer (OAKTON, USA) in degree celsius $\left({ }^{\circ} \mathrm{C}\right)$. A digital $\mathrm{pH}$ meter (Eutech Instruments) was used to determine the $\mathrm{pH}$.

Water samples for determining dissolved oxygen (DO) was fixed in the field following the modified Winkler method (Grasshoff, 1983). Water samples for chemical analysis were collected from a depth of approximately $30 \mathrm{~cm}$ below the water surface in clean 1 litre polyethylene (PE) bottles.

\section{Laboratory procedures}

Each sample was analysed for nutrient and chemical parameters such as DO, biochemical oxygen demand (BOD), chemical oxygen demand (COD), total suspended solids (TSS), ammonia, nitrite, nitrate and orthophosphate according to the standard methods (APHA, 2005), and expressed as parts per million (ppm). Water samples for ammonia, nitrite, nitrate and phosphate measurements were filtered through $0.45 \mu \mathrm{m} \mathrm{GF} / \mathrm{C}$ filters and determined using standard spectrophotometric methods.

The eutrophication assessment was based on whether the eutrophication index (E value) was greater than or equal to 1 in the nutritional status index method (Wang et al., 2009), where

$\mathrm{E}=\mathrm{COD} \times \mathrm{DIN}(\mathrm{mgL} \wedge(-1)) \times \mathrm{DIP}(\mathrm{mgL} \wedge(-1)) \times 10^{\wedge} 6 / 4500$

where, DIN is the dissolved inorganic nitrogen constituted by ammonia, nitrite and nitrate and DIP is the dissolved inorganic phosphate constituted by orthophosphate. An E value higher than 1 indicates eutrophication condition; the higher the $E$ value, the more serious the eutrophication condition.

\section{Statistical analysis}

Two-way analysis of variance (ANOVA) using SPSS 16.0 was used to analyze the effects of treatments and months on variations in nutrients. A posteriori, Tukey's HSD comparisons were applied to determine statistically significant differences at $5 \%$ level following ANOVA. Pearson's coefficient of correlation was used to calculate relationships between different parameters.

\section{Results and discussion}

\section{Water Quality}

Temperature, $\mathrm{pH}$ and salinity did not show any variation between the four treatments. Temperature profile is presented in Fig. 3. The average temperature observed for the period was $30.47 \pm 1.340 \mathrm{C}$ with the maximum observed during the premonsoon, followed by post-monsoon and monsoon. Generally, surface water temperature is influenced by the intensity of solar radiation, evaporation, insolation, cooling and mix up (Govindasamy et al., 2000). The pH varied from 7.5-7.8 during the study period (Fig. 2). Hydrogen ion concentration $(\mathrm{pH})$ in surface waters remained alkaline throughout the

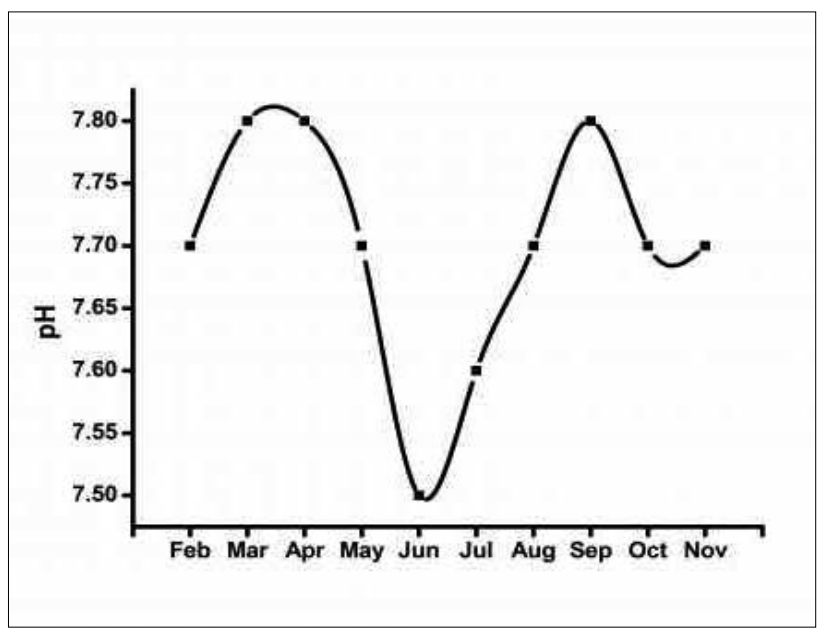

Fig. 2. Monthly variation in pH recorded during 2012 in the study area.

study period in all the treatments with minimum values occurring in the monsoon season due to decreased salinity. Generally, fluctuations in $\mathrm{pH}$ values during different months is attributed to factors like removal of $\mathrm{CO} 2$ by photosynthesis through bicarbonate degradation, reduction of salinity and temperature (Upadhyay, 1988; Rajasegar, 2003). Statistical analysis revealed that there exists a highly significant positive correlation between $\mathrm{pH}$ and salinity. $\mathrm{pH}$ usually increases due to increasing salinity and the presence of sodium-bicarbonate and carbonates (Gupta et al., 1989). Radke et al. in 2002 reported that an increase in salinity would cause a change in the solubility of $\mathrm{CO} 2$ which will cause an initial increase in $\mathrm{pH}$ after which it returns to an equilibrium due to the buffering action. Salinity during the study varied from 0.19-30 psu in all the treatments (Fig. 3) Maximum salinity was observed in premonsoon season which could be attributed to high degree of evaporation and high temperature and the minimum values for salinity was observed during the monsoon months due to the monsoon rain and freshwater input. 


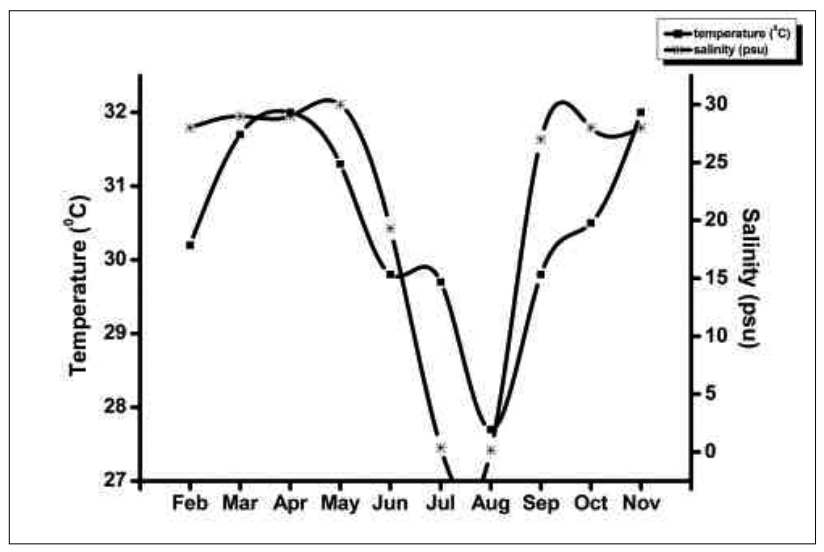

Fig. 3. Monthly variation in Temperature and Salinity recorded during 2012 in the study area.

\section{Chemical parameters}

Higher values of DO were observed in the month of August which could be due to lower temperature, higher rainfall and lower salinity (Fig. 4) and there was negative correlation of DO with temperature. Similar results were obtained by Padmavathi and Satyanarayana (1999) in the coastal waters of Godavari River. Two way analysis of variance on the results showed significant variation between treatments and months (Table 2). Among the four treatments, higher values for DO was observed in $\mathrm{T1}$ (1:0.3-fish:oysters). The higher values of DO in T1 compared to T2 and T3 could be attributed to the presence of low density of the oysters using up low DO for metabolism (Ferreira et al., 2007). Higher values in T1 when compared to T4 could be attributed to the presence of oysters whose filtration capacity reduces the turbidity thereby increasing the light penetration and thus the levels of DO. Dewey (2000) also stated that bivalves are able to improve water quality by filtering nutrients, suspended solids, and contaminants and in turn improve the DO.

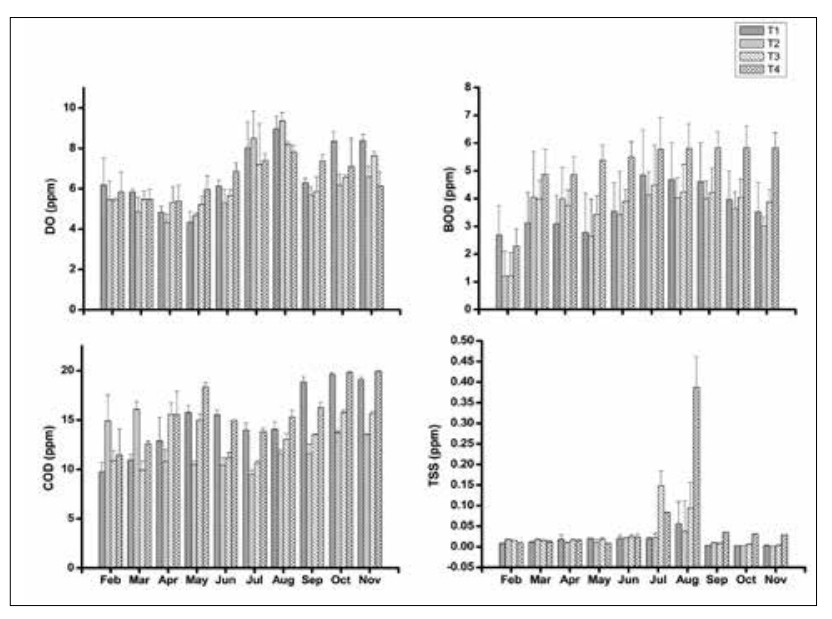

Fig. 4. Monthly variation in DO, BOD, COD and TSS during 2012 in the study area
The monthly variation in BOD and COD are shown in Fig.4. BOD provides a broad measure of the effects of organic pollution in water. COD parameter, as BOD, is used for determination of pollution level based on oxidation of organic matter with redox reaction. BOD and COD values ranged from 1.21 to $5.84 \mathrm{ppm}$ and 9.92 to $19.52 \mathrm{ppm}$ respectively. Higher values of BOD and COD were observed during post-monsoon periods due to higher temperature, increasing the decay of organic matter, using up the DO as also observed by Nandan and Azis (1990) in Kadinamkulam Kayal and Pillai (1994) in Uppanar Estuary. A test of two way ANOVA on the results of BOD and COD showed significant variations between the treatments and months (Table 2). Tukey's HSD comparison showed that treatments $\mathrm{T} 1, \mathrm{~T} 2$ and $\mathrm{T} 3$ were similar and treatment T4 was significantly $(p<0.05)$ different from others with higher values. Less DO in T4 may be due to the absence of oysters which increases the oxygen demand due to high levels of plankton and micro-organisms.

TSS values are presented in Fig. 4. Two-way ANOVA on the results (Table 2) showed significant $(p<0.05)$ differences between the treatments and months. Maximum values for TSS were observed in monsoon months which could be due to the presence of floating materials like silt, detritus etc. carried by rainwater. Lower values for TSS were observed in $\mathrm{T} 2(0.02 \mathrm{ppm})$ and higher values in T4 $(0.06 \mathrm{ppm})$. The lower values in $\mathrm{T} 2$ could be attributed to the presence of oysters which reduces the TSS. Studies conducted by Cloern (1982) and Officer et al (1982) in San Fransisco Bay have also shown that the consumption of phytoplankton by abundant stocks of bivalve suspension-feeders directly reduces the amount of suspended solids available to be remineralized by pelagic consumers and bacterioplankton. Statistical analysis revealed a positive correlation of TSS with nitrate and phosphate. An increase in TSS causes a decrease in phytoplankton (Lawson, 2011), lowering the utilization of nutrients, thereby increasing the nutrient level in water.

\section{Nutrients}

Nutrients are important parameters in the estuaries influencing growth, reproduction and metabolic activities of biotic components. Phytoplankton are filtered from the water column by the oysters and after ingestion and digestion these nutrients are made available for the metabolism and growth of oysters. Nitrogen, and to a lesser amount phosphorus, in the form of dissolved inorganic nitrogen and phosphorus (DIN and DIP) are required to synthesize proteins that help build tissues as the oyster grows. Ammonia [NH3], nitrite [NO2-] and nitrate [NO3-] constitute the dissolved inorganic nitrogen (DIN) and dissolved inorganic phosphorus is constituted by orthophosphate [PO43-] (Newell and Mann, 2012). 
Table 2. Results of Two-way ANOVA for the parameters tested during the culture period. $\mathrm{P}<0.05=$ significant

\begin{tabular}{|c|c|c|c|c|}
\hline Variable & Source of variability & df & F value & $P$ value \\
\hline \multirow{2}{*}{ DO } & Treatments & 3 & 4.880 & 0.004 \\
\hline & Months & 9 & 34.581 & 0.000 \\
\hline \multirow{2}{*}{ BOD } & Treatments & 3 & 6.112 & 0.001 \\
\hline & Months & 9 & 2.711 & 0.008 \\
\hline \multirow{2}{*}{ COD } & Treatments & 3 & 86.096 & 0.000 \\
\hline & Months & 9 & 48.675 & 0.000 \\
\hline \multirow{2}{*}{ TSS } & Treatments & 3 & 36.170 & 0.000 \\
\hline & Months & 9 & 51.977 & 0.000 \\
\hline \multirow{2}{*}{ Ammonia } & Treatments & 3 & 43.677 & 0.000 \\
\hline & Months & 9 & 37.498 & 0.000 \\
\hline \multirow{2}{*}{ Nitrite } & Treatments & 3 & .500 & 0.684 \\
\hline & Months & 9 & 9.528 & 0.000 \\
\hline \multirow{2}{*}{ Nitrate } & Treatments & 3 & 3.291 & 0.025 \\
\hline & Months & 9 & 3.980 & 0.000 \\
\hline \multirow{2}{*}{ Orthophosphate } & Treatments & 3 & 4.480 & 0.006 \\
\hline & Months & 9 & 15.652 & 0.000 \\
\hline
\end{tabular}

Among the four treatments, $\mathrm{T} 2$ was characterized by lower values of ammonia $(0.04 \pm 0.01 \mathrm{ppm})$ and higher values $(0.13 \pm 0.03 \mathrm{ppm})$ were observed in T4 (Fig. 5). Two-way ANOVA showed significant $(p<0.05)$ differences in ammonia levels (Table 2) with treatments and months. The presence of oysters in $\mathrm{T} 2$ stimulates the bacterial process of nitrification and denitrification, helping the escape of nitrogen gas, thus, lowering the ammonia content in water. Newell et al. (2005) in his studies on eastern oysters of Chesapeke Bay have reported that the biodeposits (ammonia) of oysters are oxidized to nitrite and nitrate by aerobic bacteria. The denitrifying bacteria further use the oxidized forms of $\mathrm{N}$ as terminal electron acceptors, reducing the $\mathrm{NO}_{2}$ - and $\mathrm{NO}_{3}$ - to $\mathrm{N}_{2}$ gas. Higher values of ammonia were observed in postmonsoon and monsoon which could be due to land run-off,

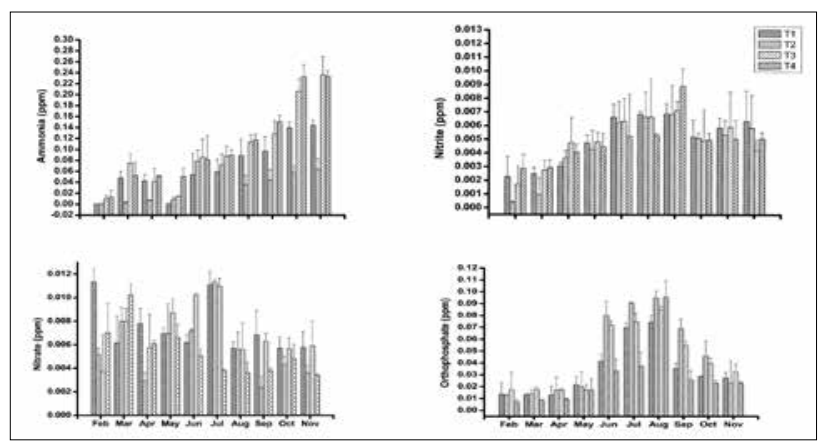

Fig. 5. Monthly variation in ammonia, nitrite, nitrate and orthophosphate during 2012 in the study area drainage and upwelling of sediments respectively as also observed by Chaudhuri et al. (2012) in Sunderbans Estuary. A positive correlation of ammonia with COD was observed. An increase in COD causes an increase in DO consumption which inhibits the nitrification process resulting in increased ammonia content.

Nitrite and nitrate values varied from 0.002 to $0.009 \mathrm{ppm}$ and 0.003 to $0.10 \mathrm{ppm}$ respectively (Fig. 5). Two way ANOVA showed that there was no significant $(p>0.05)$ variation between treatments, however significant $(p<0.05)$ difference was observed between different months (Table 2). Peak values of nitrite and nitrate were observed during monsoon which could be due to heavy rainfall, oxidation of ammonia and recycling of nitrogen. Similar findings have also been reported by Das et al. (1997) in Mahanadi Estuary, Gowda et al (2001) in Nethravathi Estuary and Rajasegar (2003) in Vellar Estuary. Lesser amount of freshwater inflow and higher salinity during the post-monsoon and pre-monsoons lowered the values of nitrite and nitrate in Uppanar backwaters during this period (Murugan and Ayyakkannu, 1991).

Treatments 1, 2 and 3 were found to be similar in DIP levels (Fig. 5) with T2 exhibiting higher levels $(0.05 \pm 0.01 \mathrm{ppm})$ and T4 showing lower levels $(0.03 \pm 0.01 \mathrm{ppm})$. Two-way ANOVA (Table 2) showed significant $(p<0.05)$ differences between the treatments and months. The removal of phytoplankton by oyster filtration in treatments 1,2 and 3 probably prevents the assimilation of orthophosphate by the phytoplankton resulting in increased level of DIP. In his studies on eastern oysters of Chesapeke Bay, Newell et al. (2005) found that bivalve filter feeding sets phytoplankton production at a lower level than that determined by the nutrients. Higher values of orthophosphate were obtained during monsoon months which could be due to the release of phosphates from sediments due to stirring action as observed by Kumar et al. (2009) in Tapi, west coast of India. A negative correlation of phosphate with temperature was also observed. An increase in temperature leads to increase in the metabolic activities which may cause the active uptake of orthophosphate by phytoplankton. Phosphate was also positively correlated with BOD since an increase in nutrients increases the phytoplankton thereby increasing the 02 demand.

At the end of the harvest, maximum harvested yield of 24.55 $\mathrm{kg}$ of fish was obtained from the treatment, T2. The yields achieved from other treatments were $23.2 \mathrm{~kg}$ (T1), 23.83 (T3) $\mathrm{kg}$ and $22.63 \mathrm{~kg}$ (T4). The harvested yield for oysters were $117.05 \mathrm{gm}$ for T1, $200.51 \mathrm{gm}$ for T2 and $57.02 \mathrm{gm}$ for T3. Maximum yield of both fish and oysters were obtained from T2 which again supports the fact that optimum stocking density favours the optimum production of the organisms cultured. 
Table 3. Mean levels ( \pm SD) of eutrophication in different treatments

\begin{tabular}{ll}
\hline Treatments & Eutrophication value \\
\hline T1 & $9.45 \pm 4.41$ \\
\hline T2 & $5.25 \pm 3.23$ \\
\hline T3 & $11.32 \pm 6.17$ \\
\hline T4 & $11.52 \pm 5.45$ \\
\hline
\end{tabular}

\section{Eutrophication assessment}

E values for all treatments were much higher than 1 indicating eutrophic conditions (Table 3). However, E value for T2 was much lesser than other treatments. Highest value for $E$ was obtained for T4. Filter feeding by populations of bivalve molluscs increase clarity of coastal waters and facilitate the removal of nitrogen and other nutrients from eutrophic waters (Rice, 2001) and this could be the reason for lower $E$ values in T2. The absence of oysters in T4 increased the E value. Though the treatments, T1, T2 and T3 (higher stocking density than T2) were stocked with oysters, lower eutrophication was found in $\mathrm{T} 2$. Studies have shown that optimum shellfish density accounts for the optimum filtration effects of oysters which leads to improved water quality (Piyathilaka et al., 2012; Cerco and Noel, 2007). The optimum stocking density of oysters in $\mathrm{T} 2$ helps in lowering the $\mathrm{E}$ value to a minimum when compared to other treatments.

From the present study it can be concluded that oysters improve water quality in a cage fish culture system by filtering large quantities of particulate matter and nutrients from the water column and thereby increased fish and oyster growth. Oyster culture had a significant influence on the oxygen and dissolved nitrogen, phosphorous concentrations in the water column. These results suggest that oyster culture could be used as a positive tool in suppressing eutrophication in addition to their primary function of food production in integrated fish-oyster farms. The study also recommends an optimal co-cultivation proportion of fish and oysters in the ratio of $1: 0.5$.

\section{Acknowledgements}

The authors acknowledge Director, Central Marine Fisheries Research Institute, CMFRI for providing facilities to carry out this work and Sophisticated Analytical Instrument Facility (SAIF), Kochi for assistance in sample analysis. The first author is very much grateful to ICAR, New Delhi for providing the fellowship during the tenure of the PhD programme. We also thank the oyster farmers of Moothakunnam area for their kind co-operation.

\section{References}

APHA. 2005. Standard methods for the examination of water and wastewater, 21st Edn., American public health association, Washington D.C., 1368 pp

Casalduero F. G. 2001. Integrated systems: "Environmentally clean" aquaculture. In : A. Uriarte and B. Basurco (Eds.), Environmental impact assessment of Mediterranean aquaculture farms. Zaragoza: CIHEAM, p. 139-145.

Cerco, C. F. and M. R. Noel. 2007. Can Oyster Restoration Reverse Cultural Eutrophication in Chesapeake Bay? Estuaries and Coasts, 30 (2): 331-343.

Chaudhuri, K., S. Manna, K. S. Sarma, P. Naskar, S. Bhattacharyya and M Bhattacharyya. 2012. Physicochemical and biological factors controlling water column metabolism in Sundarbans estuary, India. Aquat. Biosyst., 8:26.

Cloern, J. E., 1982. Does the benthos control phytoplankton biomass in south San Francisco Bay? Mar. Ecol. Prog. Ser, 9:191- 202.

Crawford, C. M., C. K. A. Macleod and I. M. Mitchell. 2003. Effects of shellfish farming on the benthic environment. Aquaculture, 224: 117-140.

Das, J., S. N. Das and R. K. Sahoo.1997. Semidiurnal variation of some physicochemical parameters in the Mahanadi estuary, east coast of India. Indian J. Mar. Sci., 26: 323-326.

Dewey, W. F. 2000. The various relationships between shellfish and water quality. In: Annual Meeting of the National Shellfisheries Association, Seattle, Washington (USA), Taylor Shellfish Company, Inc. USA. J. Shellfish Res., 19 (1): 656.

Dumbauld. B. R., J. L. Ruesink and S. S. Rumrill. 2009. The ecological role of bivalve shellfish aquaculture in the estuarine environment: A review with application to oyster and clam culture in West Coast (USA) estuaries. Aquaculture, 290: 196223.

Ferreira, J. G., A. J. S. Hawkins and S. B. Bricker. 2007. Management of productivity, environmental effects and profitability of shellfish aquaculture- the Farm aquaculture Resource Management (FARM) model. Aquaculture, 264:160-174.

Gordin, H. 1982. Aquaculture: Potential development. In: P.G. Brewers (Ed.) Oceanography: Present and Future, Springer Verlag, New York. p. 145-152.

Gordin, H., F. Motzkin, W. L. Huges-Games, and C. Porter.1981. Seawater mariculture pond. An integrated system. European Mariculture Society. Special Publication, 6: $1-13$.

Gordin, H., M. Krom, A. Neori, C. Porter and M. Shpigel. 1990. Intensive integrated seawater fish ponds: Fish growth and water quality. EAS (European Aquaculture Society), Special Publication No. 11: 45-65.

Govindasamy, C., L. Kannan and J. Azariah. 2000. Seasonal variation in physicochemical properties and primary production in the coastal water biotopes of Coromandel coast, India. J. Environ. Biol., 21: 1-7.

Gowda, G., T. R. C. Gupta, K. M. Rajesh, H. Gowda, C. Lingadhal and A. M. Ramesh.2001. Seasonal distribution of phytoplankton in Nethravathi estuary, Mangalore. J. Mar. Biol. Ass. India, 43: 31-40.

Grasshoff, K., 1983. Determination of oxygen. In: K .Grasshoff, M. Ehrhardt and K. Kremling (Eds.) Methods of Seawater Analysis, Verlag Chemie, Weinheim, p. 61-72.

Gupta, R. K., R. R. Singh and I. P. Abrol.1989. Influence of simultaneous changes in sodicity and $\mathrm{pH}$ on the hydraulic conductivity of an alkali soil under rice culture. Soil Sci., 1471: 28-33.

Kumar, N., J. I., B. George, R. N. Kumar, P. R. Sajish and S. Viyol. 2009. Assessment of spatial and temporal fluctuations in water quality of a tropical permanent estuarine system. Appl. Ecol. Env. Res.,7(3): 267-276.

Lupatsch, I. 2012. Assessing the potential of bioremediators to utilize waste products from intensive aquaculture systems using a mass balance model. In: S. Guerrero and J. Cremades, (Eds.), Integrated multi-trophic aquaculture- $A$ sustainable, pioneering alternative for marine cultures in Galicia, INTECMAR, Vilanova de Arousa (Pontevedra), p. 101

Lawson, E. O. 2011.Physico-Chemical Parameters and Heavy Metal Contents of Water from the Mangrove Swamps of Lagos Lagoon, Lagos, Nigeria. Advan. Biol. Res., 5 (1): 08-21.

McDonald, M. E. 1987. Biological removal of nutrients from wastewater: An algal-fish system model. In:K. R. Reddy and W. H. Smith (Eds.) Aquatic Plants for Water Treatment and Resource Recovery, Magnolia Publishing, Inc, p. 959-968.

Murugan, A. and K. Ayyakannu. 1991. Ecology of Uppanar backwater, Cuddalore. I. Physico-chemical parameters. Mahasagar, Bull. Natl. Inst. Oceanogr., 24: 31-38.

Nandan, S. B. and P. K. Abdul Azis. 1990. Studies on BOD and dissolved oxygen in the Kadinamkulam Kayal, Southern Kerala. Mahasagar, Bull Natl. Inst. Oceanogr., 23(2): 95-101.

Newell, R. I. E., 2004. Ecosystem influences of natural and cultivated populations of suspension-feeding bivalve molluscs: a review. J. Shellfish Res., 23: 51-62.

Newell, R. I. E. and R. Mann. 2012. Shellfish Aquaculture: Ecosystem Effects, BenthicPelagic Coupling and Potential for Nutrient Trading. A Report Prepared for the Secretary of Natural Resources, Commonwealth of Virginia, p. 1- 13.

Newell, R. I. E., T. R. Fisher, R. R. Holyoke, and J. C. Cornwell. 2005. Influence of Eastern Oysters on Nitrogen and Phosphorus Regeneration in Chesapeake Bay, USA. In: 
R. Dame and S. Olenin (Eds.), The Comparative Roles of Suspension Feeders in Ecosystems, Vol. 47,NATO Science Series: IV - Earth and Environmental Sciences. Springer, Netherlands, p. 93-120.

Officer, C. B., T. J. Smayda and R. Mann. 1982. Benthic filter feeding: a natural eutrophication control. Mar. Ecol. Prog. Ser., 9: 203-210.

Padmavathi, D. and D. Satyanarayana. 1999. Distribution of nutrients and major elements in riverine, estuarine and adjoining coastal waters of Godavari, Bay of Bengal. Indian J. Mar. Sci., 28: 345-354.

Perez, J. L. B. 2012. The challenge of a sustainable aquaculture. In: S. Guerrero and J. Cremades, (Eds.), Integrated multi-trophic aquaculture- A sustainable, pioneering alternative for marine cultures in Galicia, INTECMAR, Vilanova de Arousa (Pontevedra). p. 101.

Pillai, M. M. 1994. Hydrobiological investigations on the intertidal diatoms of the Cuddalore-Uppanar estuary (India). Ph.D. Thesis, Annamalai University, India.

Piyathilaka, M. A. P. C., M. Hettiarachchi and W.M.T.B. Wanninayake. 2012. Growth and health status of cultured edible oyster, Crassostrea madrasensis (Preston) in the Panadura estuary, Sri Lanka. J.Natn.Sci.Foundation., 40(3):201-210.

Pohle, G., B. Frost and R. Findlay. 2001. Assessment of regional benthic impact of salmon mariculture within the Letang Inlet, Bay of Fundy. ICES J. Mar. Sci., 58: 417-426.

Qian, P. Y., M. Wu and I. H. Ni. 1999. Integrated Mariculture. III. Simultaneous Cultivation of Seaweeds, Shellfishes and Fishes to Improve Seawater Quality and the Maximize Productivity. Proceedings of APEC Conference on Sustainability of Marine Environment: What Can the Private Sector Do? Kaouhsiumg, Chinese Taipei.
Radke, L. C., K. W. F. Howard and P. A. Gell. 2002. Chemical diversity in southeastern Australian saline lakes I. Geochemical causes. Mar. Freshwater Res., 53, 1-19.

Rajasegar, M. 2003. Physico-chemical characteristics of the Vellar estuary in relation to shrimp farming. J. Environ. Biol., 24:95-101.

Rice, M. A. 2001. Environmental impacts of shellfish aquaculture: filter feeding to control eutrophication. In: M. F.Tlusty, D.A. Bengston, H.O. Halvorson, S.D. Oktay, J.B. Pearce, and R.B. Rheault, JR. (Eds.), Marine Aquaculture and the Marine Environment. Cape Cod Press, Falmouth, Massachusetts, p. 76-86.

Shpigel, M., A. Neori and H. Gordin.1991. Oyster and clam production in the outflow water of marine fish aquaculture ponds in Israel. EAS (European Aquaculture Society), Special Publication, No. 14, p. 295.

Upadhyay, S. 1988. Physico-chemical characteristics of the Mahanadhi estuarine ecosystem, east coast of India. Indian. J. Mar. Sci., 17: 19- 23 .

Wang, J. K.1990. Managing shrimp pond water to reduce discharge problems. Aquacult. Eng., 9: 61-73.

Wang, J. K., C. Y. Lam and G. S. Jakob 1990. Preliminary investigation of an oystershrimp joint production system. Trans. Am. Soc. Agric. Eng., 33(3): 975-980.

Wang, X. L., Z. G. Cui, Q. Guo, X. R Han and J. T. Wang. 2009. Distribution of nutrients and eutrophication assessment in the Bohai Sea of China. Chin. J. Oceanol. Limnol., 27(1):177-183. 